Chapman University

Chapman University Digital Commons

English (MA) Theses

Dissertations and Theses

Summer 8-2020

\title{
Trauma Begetting Trauma: Fukú, Masks, and Implicit Forgiveness in the Works of Junot Díaz
}

Jacob VanWormer

Chapman University, vanwo101@mail.chapman.edu

Follow this and additional works at: https://digitalcommons.chapman.edu/english_theses

Part of the Literature in English, North America Commons

\section{Recommended Citation}

VanWormer, Jacob. Trauma Begetting Trauma: Fukú, Masks, and Implicit Forgiveness in the Works of Junot Díaz. 2020. Chapman University, MA Thesis. Chapman University Digital Commons, https://doi.org/ 10.36837/chapman.000197

This Thesis is brought to you for free and open access by the Dissertations and Theses at Chapman University Digital Commons. It has been accepted for inclusion in English (MA) Theses by an authorized administrator of Chapman University Digital Commons. For more information, please contact laughtin@chapman.edu. 


\title{
Trauma Begetting Trauma: Fukú, Masks, and Implicit Forgiveness in the Works of Junot Díaz
}

\author{
A Thesis by \\ Jacob VanWormer \\ Chapman University \\ Orange, CA \\ Master of Arts in English \\ August 2020 \\ Committee in charge: \\ Brian Glaser, Ph.D., Chair \\ Rei Magosaki, Ph.D. \\ Joanna Levin, Ph.D.
}

Wilkinson College of Arts, Humanities, and Social Sciences

Submitted in partial fulfillment of the requirements for the degree of 
The thesis of Jacob VanWormer is approved.

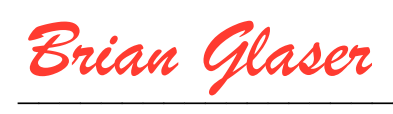

Brian Glaser Ph.D., Chair

Rei Magosatei

Rei Magosaki, Ph.D.

Goanna Levin

Joanna Levin, Ph.D.

July 2020 
Trauma Begetting Trauma: Fukú, Masks, and Implicit Forgiveness in the

\section{Works of Junot Díaz}

Copyright () 2020

by Jacob VanWormer 


\begin{abstract}
Trauma Begetting Trauma: Fukú, Masks, and Implicit Forgiveness in the Works of Junot Díaz by Jacob VanWormer
\end{abstract}

This essay began as an examination of Junot Díaz's combination of "low" and "high" culture art and literature in The Brief Wondrous Life of Oscar Wao. In the wake of Díaz publishing "The Silence: The Legacy of Childhood Trauma," and the subsequent accusations of abuse against him, it seemed irresponsible to examine the text in such a way without considering this new information. It was both more topical and relevant to re-examine the portrayal of Díaz's recurring tragic playboy narrator through two short story collections and a novel, making note of the character's proximity to Díaz's own life story as presented in “The Silence," and considering the implicit forgiveness offered to both the character and the author via framing their struggles with sexual misconduct as central tragedy, and those they hurt as functional props to those narratives. The purpose here is not to cast judgment on Díaz, but to use this added context to interrogate the male-dominated society he writes, which ensnares and encapsulates all the characters under his pen. 


\section{TABLE OF CONTENTS}

Page

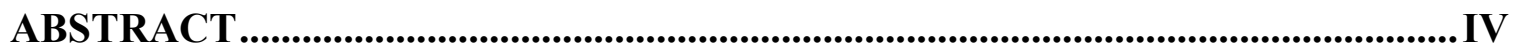

1 TRAUMA BEGETTING TRAUMA: FUKÚ, MASKS, AND IMPLICIT FORGIVENESS IN THE WORKS OF JUNOT DÍAZ............................................... 1

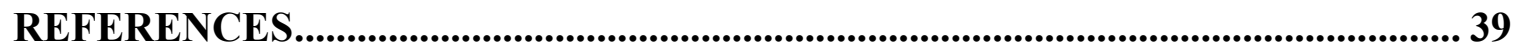




\section{Trauma Begetting Trauma: Fukú, Masks, and Implicit Forgiveness in the Works of Junot Díaz}

In lucha libre, there is a tradition. Wrestlers wear masks, hiding their true identities and donning personas, sometimes heroic, sometimes villainous, but always larger than life. Hulking titans collide, muscles rippling in a display of peak machismo, and the audience cheers and feeds

into the illusion. These are not men, these are gods. They have no weaknesses, no faults. Wearing the mask, they are symbols, invincible pillars of masculine dominance. To have one's mask removed, to expose the raw humanity underneath, is the greatest dishonor. When a mask is removed, and a face revealed, the illusion is shattered. Under the mask, there is just a beaten man, and that is somehow lesser.

Junot Díaz is a writer, not a wrestler, but for much of his life, he was worn a metaphorical mask to hide the wounded man underneath. Díaz was raped multiple times when he was eight years old by an adult he trusted, something he only acknowledged publicly in his $2018 \mathrm{New}$ Yorker article "The Silence: The Legacy of Childhood Trauma." At the time, he did not tell anyone, for fear of backlash, both directly from his assailant and from society around him. Growing up Dominican, he writes that he had a very particular idea of masculinity driven into him, which drove him to hide the assault:

I was confused about why I didn't fight, why I had an erection while I was being raped, what I did to deserve it. And always I was afraid — afraid that the rape had "ruined" me; afraid that I would be "found out"; afraid afraid afraid. "Real" Dominican men, after all, aren't raped. And if 
I wasn't a "real” Dominican man I wasn't anything. The rape excluded me from manhood, from love, from everything. (Díaz, "The Silence”)

Through “The Silence," Díaz tells the story of how this trauma shaped his growing up. He writes about nightmares and depression, about suicide attempts, about an initial revulsion to sex becoming a compulsion to cheat in every relationship he ever had. And he tells us how he has gotten better, he's in therapy, he's in a steady relationship with a woman who "knows everything about my past" (Díaz, "The Silence"). In the end, he reflects:

I think about you, X—. I think about that woman from the Brattle. I think about silence; I think about shame, I think about loneliness. I think about the hurt I caused. I think of all the years and all the life I lost to the hiding and to the fear and to the pain. The mask got more of me than I ever did. But mostly I think about what it felt like to say the words - to my therapist, all those years ago; to tell my partner, my friends, that I'd been raped. And what it feels like to say the words here, where the whole world—and maybe you-might hear. (Díaz, "The Silence”)

The one apology Díaz makes in the piece is to X-, a woman at a book signing, who after reading his books, asked if he had been raped, and who he told no. He does not apologize for his cheating. In fact, he almost paints himself as more the victim of his cheating than his partners. When confronted by the supposed love of his life with evidence of his cheating, Díaz writes that he blacked out, and not even his winning the Pulitzer Prize was enough to stop her from throwing him out, and the rest of the piece is dedicated to the downward spiral he underwent in the wake of her discovery, and his struggle to recover from that. In a piece seemingly acknowledging, 
explaining, and apologizing for the pain Díaz caused, the focus is singularly rooted on his own pain, and his journey to recovery independent of any of the women he hurt.

There is an unspoken thesis which runs through "The Silence," and that is that personal trauma excuses abusive behavior, and personal growth and partial admittance are deserving of forgiveness. The cheating was just a symptom of his personal struggle trying to hide his past as a rape survivor, and so should not be considered independent of the trauma that incited it. Shortly after "The Silence" was published, Zinzi Clemmons accused Díaz of forcibly kissing her when he she invited him to be a guest speaker in her grad program (Alter, et al,. The New York Times). Monica Byrne accused him of "repeatedly shouting rape in [her] face," after a minor disagreement at a dinner after a talk he gave (Byrne), and shouting her down for the rest of the evening. Carmen Maria Machado accused him of aggressively responding when she asked about his recurring protagonist's "unhealthy pathological relationship with women" during a Q\&A session (Maria Machado).

In the wake of these accusations, Díaz stepped down from his position on the Pulitzer Prize board, and faced a period of scrutiny. In an initial statement delivered to the New York Times through his agent, Díaz did not acknowledge specific accusations, but stated "I take responsibility for my past. That is the reason I made the decision to tell the truth of my rape and its damaging aftermath. This conversation is important and must continue. I am listening to and learning from women's stories in this essential and overdue cultural movement. We must continue to teach all men about consent and boundaries." (The New York Times). Several months later, after both MIT and The Boston Review concluded internal investigations into Díaz and maintained his position as professor and fiction editor respectively, Díaz denied Clemmons' accusation, and called his initial 
statement "the worst thing I've written, the worst thing I've put my name to" (The LA Times). The accusations were largely dismissed, and the literary world quietly moved on.

It is not my place to speculate on the accusations levied against Díaz, or to judge the responses, but such a strong denial of an initial statement that an agent approved, which did not implicate himself and simply pushed for these women to be listened to and considered, so quickly after his name was cleared, seems to hold a dark implication. We should be sympathetic to the stories of victims of abuse, just not the wrong ones.

It is with this light, that I wish to return to Machado's initial comment which drew Díaz's ire. I would argue that "an unhealthy, pathological relationship with women" runs through both “The Silence," and through Díaz's fiction in Drown (1996), The Brief Wondrous Life of Oscar Wao (2008), and This is How You Lose Her (2012) in identical patterns. Men plagued by past sexual assault and cultural and societal pressure, acting out through sexual misconduct, turning sexual partners into objects, props in their personal quests for self-acceptance or recovery, unavoidable casualties in the war to mask their shame, a shame rooted deeply in Díaz's depiction of Dominican masculinity.

The conception of Dominican masculinity Díaz describes in "The Silence" and in his fiction is fickle, policed with strict boundaries, and reliant on fragile, archaic constructs of what it means to be male. Masculinity here is an unsustainable ideal denoted at birth which must be nurtured and maintained through every action of one's life. If it is lost, it can never be regained. It's a struggle that most of Díaz's protagonists, young Dominican men themselves, are intimately familiar with. But more than machismo alone, many of his characters are impacted by their own traumatic experiences, both inflicted and received. 
"The Silence" contextualizes many of the subtleties Díaz worked into his characters, drawing subtext out into raw text and painting most, if not all, of his characters as victims in a generational cycle of sexual trauma in a world where aggressive sexual behavior is the number one requirement to fulfill gender roles. This omnipresent weight of presupposed, performative gender is weaved into every character Díaz writes, and nowhere do we get a clearer view of it than in his recurring narrator Yunior de la Casas. Through Díaz's writing, we see Yunior as a child, a teenager, a young adult and beyond, often narrated in first-person most reflective of his voice, and as such we get a uniquely broad view of his growth and development and of formative experiences throughout his life.

I would like to quickly note that I am not writing to comment on Dominican culture as a whole. I have not lived or studied the Dominican experience, and I am not making sweeping statements on a complex culture based on one author's writing. I am only examining Díaz's particular presentation, which, as fiction, carries its own narrative intent and limitations. It is one portion of that narrative that I am exploring here.

It is best to begin by defining two concepts: fukú and tíguerismo. Fukú, full name Fukú Americanus, as defined by Yunior in The Brief Wondrous Life of Oscar Wao, is "generally a curse or a doom of some kind, specifically the Curse and the Doom of the New World" (Oscar Wao 1). Originating when "the Admiral," Christopher Columbus, left unnamed because "to say his name aloud or even to hear it is to invite calamity on the heads of you and yours" (Oscar Wao 1), "discovered" the new world and immediately set to brutalizing the people he found there. The Admiral died "miserable and syphilitic," but the curse brought on by his actions lived on to haunt the Americas, and Caribbean people in particular. Yunior attributes the suffering of Oscar and his family to fukú, and states that every Dominican family has a fukú story. If there was pain to be 
had, fukú, apparently, was the cause. Trent Masiki summarizes Fukú as "the European rape of the New World, the discourse of white supremacy, and the public silence that continues to sustain and perpetuate these traumatizing realities." (Masiki)

Tíguerismo is a particular breed of Dominican machismo, the ideal to which all Dominican men are upheld. "Hypermasculinity," as Masiki puts it. To be a Dominican man is to be a tiger, a tíguero, and to be a tíguero, you need to meet several unspoken criteria:

Criteria one: you must be heterosexual. A tíguero is a ladies' man, preferably with the emphasis on the plurality. If there aren't women falling at your feet to be next in line, and you aren't picking back up as many as you can, you are no tíguero.

Criteria two: Playing off of that, a tíguero must be sexual. If you can still count how many women you have obviously left screaming for more, then there is more work to be done.

Criteria three: A tíguero is also a man's man. When you aren't on the warpath of seduction, you should be enhancing your masculinity by working out, honing your body for future engagements, or bragging about your most recent conquests. The only way a man can truly find camaraderie with another man is through a shared love of women, or the mockery of those who don't know it. This brings me to the most important of all.

Criteria four: A tíguero is powerful, and because he is powerful, a tíguero must ensure he is an unquestioned idol of masculinity. To enforce this, it is important to insult and deride anyone you see as lesser. Weak men, gay men, women. If someone doubts your tíguerismo, you use that finely honed body to convince them otherwise. A tíguero takes what he wants without question. 
Waver on any of these points, lose your tíguerismo, and it can never be regained. Tíguerismo is machismo is toxic masculinity, but it is toxic masculinity intertwined with cultural identity, with deep roots historically, socially and politically. Tíguerismo has the power of tradition behind it. That's precisely where fukú comes in.

Yunior describes fukú as an unbreakable magical curse that no one can escape, and he's partly correct, but in Oscar Wao, this is discussed in a literal sense. I'd like to propose an alternate take, building off of Masiki's interpretation. Fukú is a legacy of violence, often sexual violence, perpetuated by a system of strong men in power, taking what they want and destroying anyone and everyone who would dare to question their right to it. Fukú is embodied in Oscar Wao most in the figure that Yunior dubs its "high priest" (Oscar Wao 2), Dominican dictator-for life Rafael Leonidas Trujillo Molina who ruled from 1931-1961. Trujillo acted as most dictators did. His will was ironclad, his every wish was law. He burned any writings that questioned him, he kidnapped any women he desired, of which there were many, and he tortured and killed anyone who spoke out in opposition. Trujillo was a blight on the Dominican Republic, and he fittingly styled himself after Christopher Columbus. Under Trujillo's reign, the Faro de Colon (Lighthouse of Columbus), a museum dedicated to Columbus, began construction. As Jason Cortes puts it: "With his fetishistic attraction for monuments, the Faro de Colón gave Trujillo the opportunity to claim the image of the Admiral as an emblem of Santo Domingo ("Land He Loved Best") while asserting their European inheritance vis-à-vis the Haitians’ African one”(Cortes 109). Inscribing "Era de Trujillo, 1944" on the initial cornerstone of the building, Trujillo cemented his connection to Columbus, two vicious tyrants, whose violent sexual appetites and desires, and the legacies thereafter, have tormented the island and its inhabitants ever after. 
Trujillo's influence on Oscar Wao is direct, though he is dead at the time the novel opens. Oscar's mother, Beli, grew up in the Dominican Republic under the Trujillo dictatorship. Her father was tortured and murdered for both refusing to bring his older daughters to meet Trujillo and for writing critically about his dictatorship. While Beli, his youngest daughter, had survived hidden away in the care of her aunt, she was later tortured, maimed, and beaten nearly to death when she fell in love with one of Trujillo's higher-ups and attempted to carry his child against his wishes. During most of the novel's events, Trujillo is dead, but his legacy carries on, haunting every Dominican. Even the capitán, who ultimately orchestrates Oscar's death, is a remnant of the Trujillo era. "He'd been young during the Trujillato, so he never got the chance to run with some real power, wasn't until the North American Invasion that he earned his stripes. Like my father, he supported the U.S. Invaders, and because he was methodical and showed absolutely no mercy to the leftists, he was launched - no, vaulted - into the top ranks of the military police" (Oscar Wao 295). Two decades after Trujillo's death, the militaristic use of power and violence to stake claims, particularly on the bodies of women (Oscar's affection for the capitán's girlfriend Ybón is what gets him killed, after all), is as pervasive as ever. And it's that pervasiveness that embodies fukú.

Fukú, as I read it, is an intangible, omnipresent force, but it is not a magic curse. It's the result of centuries of long-standing male empowerment, enforced by violence, augmented by other centuries-old power divisions (race, sexuality, wealth), and propped up by the sheer power to beat anyone who stands against it into the dirt and paint them as radical threats to society. Fukú is generation after generation raised to understand abusive social norms as "just how things are done," systematized and further ingrained in the wake of European colonization. Fukú is taking in biases so deep from such a young age they can take lifetimes to unlearn. Fukú is toxic masculinity, 
it is the entitlement of those in power to take what they want, and it is the weakness those who are victimized by it feel, the powerlessness to change the minds of millions. Millions who are not only benefiting, but who are often actively taught that to attempt to circumvent this status quo is abnormal, treasonous, probably a sin.

Following this logic, fukú is not strictly Dominican. Yunior even says fukú is responsible for the death of John F. Kennedy, and why wouldn't the Doom of the New World claim its thenmost-prominent, warmongering playboy face? The history of the United States is riddled with that same toxicity. But fukú extends beyond the Americas, too. After all, fukú supposedly began with one powerful European setting his boots on the wrong shore and inflicting his might on the people he found there. Or did it begin even earlier? On a global scale, Columbus was far from the first colonizer, the first enslaver, the first power trip. Countless societies have been built on the supposed rights of men at the expense of anyone and everyone those particular men deem lesser, and the unquestioning acceptance of that fact oozes into every layer of those societies. The Dominican Republic just seems to have gotten a particularly raw deal.

Take all of that history, all of those inherited biases and understandings, and pair it with the expectation that you must aspire to become a veritable Adonis or else give up your right to any place in your culture. Now shatter it with tragedy at eight years old.

When Díaz was raped, he says his life abruptly stopped. He describes the boy before the incident as a stranger. All the typical worries of childhood were replaced with an urgent need to hide. If he lost his chance to be a man at such a young age, what would his life be like? He was hurt, physically and emotionally, but revealing that hurt was a potential source of even greater shame and pain. So he crafted his first mask and tried to lock away that trauma, but all through his 
growing up, it seeped through the cracks. He writes that he suffered depression, rage, and horrific nightmares where trusted figures violated him, from which he would wake up having bitten his tongue until it bled. In his senior year of high school, he tried to kill himself, and when that failed, the only thing that stopped him trying again was an acceptance letter to Rutgers University. He went, and took advantage of the distance from his former life:

At Rutgers I buried not only the rape but the boy who had been raped - and threw into the pit my family, my suffering, my depression, my suicide attempt for good measure. Everything I'd been before Rutgers I locked behind an adamantine mask of normalcy. And, let me tell you, once that mask was on no power on earth could have torn it off me. (Díaz, "The Silence")

He became a runner and a weightlifter, and he started to date. Anything and everything to craft the persona of a "normal" life. This did nothing to overcome the trauma, but he got better at hiding it. He also started writing, and he created Yunior (de Las Casas in Oscar Wao), a character who shared much of his life experience.

Yunior wears a mask of his own through Díaz's two short story collections, and The Brief Wondrous Life of Oscar Wao. But using Díaz's experience with trauma as defined in "The Silence," his struggles and pain, the subtle clues become more evident in his characters therein. Their unique but similar struggles seem to show Díaz repeatedly examining damaging sexual behavior, the individual repercussions to both parties, and the inherited trauma that weaves from character to character. Fukú is there at every moment, nudging characters in such a way as to spread itself back and forth between them, the after image of sexual assault, but also the urge that drives it in the first place. Both the pain and the guilt, driving perpetrator and victim at the same 
time. This is the most common guise it takes throughout Díaz's works, and particularly with regard to Yunior's stories. Whether one is victim or perpetrator, once touched, the trauma, the Fukú, festers. It impacts every interaction one has moving forward, and most importantly, it continues to spread.

To view this properly, we must define some prominent signs of sexual trauma in these characters. Díaz was writing in part from personal experience, and he was well-versed in hiding his own trauma, a skill that extends to Yunior. As the narrator of his own stories, most often in a first-person form, Yunior's words and focus are very particularly chosen to keep the reader from seeing beneath his mask, the pain as rooted in trauma. Without looking for fukú, you might miss it. But Yunior shares much of his experience with Díaz, down to the symptoms of his unaddressed trauma. The most obvious of these is the aforementioned symptom of biting his tongue in his sleep. Díaz's nightmares drove him to bite his tongue until it bled (Díaz, "The Silence"), and Yunior is much the same, though his narration often dismisses or underplays it. All through "Miss Lora," Yunior is plagued by nightmares blending apocalyptic scenarios with sexual encounters with the titular Miss Lora, and each time he wakes up to find his tongue bitten and bleeding.

Both Díaz and Yunior lift weights seemingly in response to trauma, Yunior doing so to a much greater extent and becoming large enough that people notably feel the need to touch his muscles: "People always touched you. You were used to it. You were an amateur weightlifter, something else you did to keep your mind off the shit in your life." (Díaz, Lose Her 156) The purpose of this is two-fold. Building muscle creates a more traditionally masculine body, drawing Yunior closer to that tíguerismo ideal that he would be so afraid of losing if he admitted he was a victim, but it also seems to me as a reclamation of his body. It's a common after-effect of sexual abuse to have a damaged self-image, and one method of coping with that is to attempt to "improve" 
one's body through exercise, or to become stronger to better fend off a possible future attack. Muscle, power, masculinity. All of these things together equal control. To lose them is to lose agency over oneself, but to lose agency is equally to lose masculinity. In practice, this is a sexist and impractical worldview, but for Yunior and the other characters who spend their lives entrenched in it, this is the way the world works.

Emotionally, they are victims themselves insofar as they carry a sense of unwarranted guilt, lack of self-worth, depression, or an associated predisposition toward recklessness or selfdestruction. When it comes to sexual relationships after abuse, there are two common responses. The first is to shy away from physical contact, and sometimes to give up on sex altogether. The other is to attempt to reclaim one's sexuality by doubling down and becoming very sexually active. The latter option is the only real choice for Yunior, who, after some initial hesitation, dives headon into the tíguero lifestyle early in high school, a noted distinction from Díaz himself, where Yunior becomes larger than life.

All of these traits are present in Yunior, and most of them are present in the other characters he interacts with, particularly those he shares sexual experiences with, willingly and otherwise. To best illustrate this, I'd like to move through Yunior's life, from his youngest appearance in Drown, and moving forward through the loose timeline which is established subsequently in Oscar Wao and This Is How You Lose Her.

Described by Díaz as “a young Dominican man who, unlike me, had been only a little molested" ("The Silence"), Yunior grows up between the pages, starts to work out, starts to date, starts to sleep around on the women he's dating, and then continues to do so until he starts to collapse under the weight of the repetition. This is his mask, his protection. 
Performative masculinity is the name of the game, but it's a hollow masculinity. The echo of an echo of an idea. Yunior's primary male role models are his older brother Rafa and his father, a former officer under Trujillo, who is absent for the first nine years of his life, moving to the United States to make money to bring his family after him. His father is described as "a cloud of cigar smoke, the traces of which could still be found on the uniforms he'd left behind. He was pieces of my friends' fathers, of the domino players on the corner" (Díaz, Drown 70). Cigars, military uniforms, and the local men gambling, a hodgepodge collection of the ideas of what a man might be. Rafa, meanwhile, is already indoctrinated into the performance, chasing girls and getting in fights as soon as he can walk. The combination of the two enforce the path laid out for Yunior. What we see of their father when he re-enters their lives briefly and brings them to the United States isn't promising. In "Fiesta, 1980," the one story in the collection in which Yunior interacts with his father directly, he is short-tempered and violent to both his wife and his sons, and he is cheating with an unnamed Puerto Rican woman. Yunior and Rafa are both aware of his cheating and mull over whether and how to tell their mother. They settle on hiding it and by extension join the discourse of silence surrounding sexual misconduct that will come to define both of their lives and romantic interactions for the foreseeable future. Rafa will dive headlong into the sucio (playboy) life for as long as he lives, but Yunior will be reluctant well into high school. Before Yunior finishes high school, before Rafa dies of leukemia, their father leaves them again, this time for good "for his twenty-five-year-old" (Díaz, Lose Her 36), and cementing himself as the archetypal sucio, the tíguero to which they have no choice but to measure up.

Yunior first appears in the story "Ysrael" at nine years old. The story is fairly short and mostly straightforward, and details an afternoon in which he and then-twelve-year-old Rafa, living in the Dominican Republic, travel to the countryside to see the face of another young boy, Ysrael, 
whose face was eaten by a pig when he was young, and who wears a luchador-esque mask to hide the scarring and damage the incident caused. Much of the story deals with establishing the local legend of Ysrael. "He's ugly [...] that face of his would make you sick!" (Díaz, Drown 8) one boy tells Yunior, and the rumor mill around how bad it was reduces the boy to some grotesque display, rather than a human being and a victim of a tragic accident. Rafa decides they have to see his face and convinces Yunior to come along. The journey to find Ysrael is unremarkable, save for a moment in which Rafa attempts to cheat himself and Yunior onto a bus without paying the fare. He pushes Yunior onboard and sits him in the back, then poses as a cobrador, a fare collector, arguing that while passing the fares he collects onto the real cobrador, he also paid for their passage. While he is conducting this scheme, Yunior is left alone on the bus with an older seatmate and a grease stain on his pants. The older man, whose arms are described as "ropy with muscle" notes the stain and tells him he needs to be careful. Then we get this paragraph:

Let me help. He spit in his fingers and started to rub at the stain but then he was pinching at the tip of my pinga through the fabric of my shorts. He was smiling. I shoved him against the seat. He looked to see if anybody had noticed. (Díaz, Drown 12)

Yunior curses at the man, who then grabs him by the arm and tells him to watch his mouth. Yunior flees toward the door. Rafa gets in a brief scuffle with the cobrador, firmly denies the young man when he tries to grab him, and then the two leave the bus without paying at which point Yunior begins to cry. Rafa calls him a pussy and threatens to leave him there. Yunior manages to stop himself, and the two continue on.

This sequence, which takes place over just two pages interspersed with Rafa's scheming and is never directly mentioned again, demands attention. Yunior is sexually assaulted by a man 
who gets little description beyond his musculature. When he tries to fight back, he is grabbed and threatened. Immediately after, he sees Rafa push off someone trying to grab him, and when he lets his emotions show and cries over what he has just experienced, he is berated and threatened with abandonment. When he catches up with Rafa, he gets lectured:

Are you always going to be such a pussy?

I wouldn't have raised my head if God himself had appeared in the sky and pissed down on us.

Rafa spit. You have to get tougher. Crying all the time. Do you think our papi's crying? (Díaz, Drown 14)

Even if Rafa thinks Yunior's crying is over the minor crime they've committed, he is Yunior's single, present masculine role model, and he has just cemented that this event, which will haunt Yunior for the rest of his life, can never be acknowledged without sacrificing his masculinity. This will be a formative moment for Yunior. In this moment, though he may not fully comprehend yet, his mask will begin to form as his requisite silence sets in.

Additionally, though it is only briefly mentioned, this scene begins a trend of traumatized individuals enacting trauma. Given the theme of muscle among trauma survivors which will continue to develop, the man on the bus's arms being muscular, as one of two seemingly tangential descriptors, to me is indicative of a possible encounter in his own past. These are themes we'll revisit, but which here seem to just be beginning to form.

When Yunior calms down, he and Rafa set off to find Ysrael, and when they do, they find he is an intimidating figure. "He was about a foot bigger than either of us and looked like he'd 
been fattened on that supergrain the farmers around Ocoa were giving their stock" (Díaz, Drown 15). And of course, he is wearing his mask, handsewn, revealing bits of scar tissue around his eyes. They make small talk and Yunior attempts to befriend Ysrael, learning that doctors in the US apparently want to operate to restore his face. At this point Rafa abruptly smashes a glass bottle over the masked boy's head, kicks him, wrestles him to the ground and tears off his mask. The two examine the damage done all those years ago, Yunior notably disturbed, Rafa indifferent, then they leave him there. On the way home, Yunior says "Ysrael will be OK," but Rafa strikes it down firmly and that's the end of the conversation.

Yunior's concern for Ysrael is two-fold. He seems to genuinely hope for Ysrael's recovery, but between his words, it seems he is really concerned with his own recovery after the earlier incident on the bus.

Ysrael is a unique case among Díaz's characters, and he is one of the few to get a story dedicated to him without Yunior's involvement, instead told by an omniscient, third-person narrator. The story, called "No Face," follows a day in the life of Ysrael while he waits to learn if he will travel to Canada for a procedure to reconstruct his face, and from line one, the connection is present. "In the morning, he pulls on his mask and grinds his fist into his palm" (Díaz, Drown 153). The grinding fist, a display and reminder of the machismo he must wear to accompany the mask, to show that he is more than his injury. He begins his day with an intense workout, then spends the rest running around performing errands. At one point, he is attacked by a group of boys. A fat one sits on his chest, and they threaten to "turn him into a girl" (Díaz, Drown 156), which could be interpreted several ways, all of them terrible and indicative of sexual assault. Ysrael is strong, though, and pushes them off and flees. 
Later in the story, we learn that he has frequent nightmares of the pig that attacked him coming back to finish the job. "No one has hidden it from him. They tell him the story over and over again, as though afraid that he might forget" (Díaz, Drown 157). He has been told this story repeatedly. It is a part of him that cannot be ignored, cannot be moved on from. It's what defines him to anyone and everyone else he meets. Perhaps most telling is the ending of the section: "When he awakens he's screaming and blood braids down his neck; he's bitten his tongue and it swells and he cannot sleep again until he tells himself to be a man" (Díaz, Drown 158). Ysrael is suffering from the same recurring nightmares, the same violation of his body, the same lingering after effects of a traumatic childhood experience that we will see in Yunior in later stories. But his assault was purely violent rather than sexual, and notably, unlike Yunior's, has left visual scars that cannot be hidden. Ysrael can wear a mask to obscure the damage, but everyone knows what happened to him, everyone can see that something is wrong and that the mask is just there to spare them the grotesque details. He will forever be "the boy whose face was eaten." And so he works out as hard as he can, he builds himself into a man. He idolizes masked wrestlers and superheroes, and he embraces the mask and looks forward to the possible future in which he can "fix" himself, but he doubts it can ever truly change him. Ysrael's mask is Yunior's mask made physical, and his life, defined to the world by his trauma permanently and irrevocably, is Yunior's greatest fear.

When Yunior and Rafa tear off his mask, it is a betrayal of the meager trust they had built, but it could not have been a shock. Ysrael knows his life, knows his image. They're just another group of boys harassing him on the street. And that's the last we see of him.

Yunior's life, however, goes on visibly, and the next point I'd like to examine is defined by two stories which mirror each other and which heavily impact Yunior: "Drown" in Drown, and "Miss Lora" in This Is How You Lose Her. In both stories, a high school-aged Yunior is sexually 
victimized by two very different individuals: his then-best friend, Beto, and an older woman and friend of his mother's, Miss Lora. "Ysrael" is the story that creates Yunior's fear, but it is in these two stories that we see Yunior's mask, and his perceived need for it full form. Masiki examines both stories in depth, through the lens of a 2003 interview in which Díaz explained he often writes female characters as doppelgängers for his male characters, examining the different reaction and results to similar actions based on different privileges and societal roles. Masiki takes the doppelgänger theory to its logical conclusions, envisioning Miss Lora as a doppelgänger for Beto in "Drown," as well as various minor characters throughout "Drown," which act as doppelgängers for Yunior and Beto.

"Drown" takes place in the year after Yunior graduates high school. He is living at home, selling marijuana and generally going nowhere, when he hears that his former friend Beto is back in town, and thinks back on their relationship when they were in school. After Rafa died, Beto was Yunior's closest friend, and filled a sort of replacement older brother role. Beto was calm, collected, always had Yunior's back, although he always pushed him to shoplift. During these outings, Beto always kept a cool head, and kept them out of trouble. The one time they got caught, hiding under a vehicle after fleeing the police, Yunior started to cry, something he wouldn't have been comfortable doing in front of most anyone, and Beto's response is wholly unlike Rafa. "Beto didn't say a word, his face stretched out and gray, his hand squeezing mine, the bones in our fingers pressing together" (Díaz, Drown 99). He doesn't berate Yunior, doesn’t threaten to abandon him there. He just offers the small comfort in a clasped hand, an oddly intimate gesture for two teenage boys playing at machismo. It seems clear the two care for each other, which makes the following scenes that much more difficult. 
"Twice. That's it" (Díaz, Drown 103). It's an ominous beginning to a section of a book. Yunior and Beto are at Beto's parents' apartment after an evening at the public pool, watching a porn film that belongs to Beto's father. Beto explains that his father watches the tapes in the middle of the day with his mother home, and that he "would sit down with his pop and neither of them would say a word, except to laugh when somebody caught it in the eye or the face" (Díaz, Drown 104). An hour into the film, Beto reaches over and slips his hands down Yunior's shorts. Yunior is initially shocked. He doesn't stop Beto, but the particularly stark description, devoid of Yunior's typically colorful commentary, speaks for itself:

His hand was dry. I kept my eyes on the television, too scared to watch. I came right away, smearing the plastic sofa covers. My legs started shaking and suddenly I wanted out. He didn't say anything to me as I left, just sat there watching the screen. (Díaz, Drown 104)

The incident is reminiscent of the bus when Yunior was a child, taken a step further, but with an additional wrinkle. Beto is Yunior's closest friend, not a stranger. Where before Yunior reacted immediately with indignation, here his primary emotions seem to be shock at the betrayal of trust, or fear to actually show concern and admit his weakness in the moment. We don't get to hear his reasoning, whether he let Beto continue because he was confused, whether he thought he should go along with it for his friend's sake, or whether it was just pure terror. Whatever the reason, Yunior makes a quick exit, and when Beto calls him the next day, "when I heard his voice I was cool but I wouldn't go to the mall or anywhere else" (Díaz, Drown 104). Yunior is clearly distraught and upset over the incident, but in the end, he relents, because Beto is his best friend "and back then that mattered to me more than anything" (Díaz, Drown 104). He meets Beto at the pool. Beto is described here as pale and flabby under the water, not in line with established bodily masculinity. Perhaps Yunior notices this now because of Beto's coming out, his homosexual 
behavior marking him as feminine to Yunior's binary worldview. It also seems to mark Beto as someone who has not been molested in his time, though that cannot be said for certain. The two watch as a group of boys steal a bathing suit top from a girl, Yunior describes as "stupid enough to hang out alone" (Díaz, Drown 105). Yunior blames the girl for putting herself in this vulnerable situation, when he is doing the same thing, turning his internalized guilt outward and reinforcing the grip of this twisted worldview, while at the same time subconsciously aligning himself with the victimized girl; a doppelgänger, per Masiki. Beto puts his hand on Yunior's shoulder and tells him "Let's go," and Yunior goes along quietly, playing the victim to Beto's sucio. Back at Beto's place:

"We sat in front of his television, in our towels, his hands bracing against my abdomen and thighs. I'll stop if you want, he said and I didn't respond. After I was done, he laid his head in my lap. I wasn't asleep or awake, but caught somewhere in between, rocked slowly back and forth the way surf holds junk against the shore.” (Díaz, Drown 105)

Junk adrift on the tides is an apt metaphor for Yunior, who must feel completely at the mercy of Beto in this moment, but on a broader scale is at the mercy of the omnipresent interpretation of trauma and masculinity that is fukú. This encounter is not the tide, it's a wave. The tide is a combination of the societal force that treats victims as lesser and the internalization that because of that, there is nothing to be done but to accept that same force.

This scene, due to the lack of internal emotion from Yunior, who is typically quite candid, leads to conflicting interpretations. When Beto says that he will stop, it can be interpreted as a limp attempt at acquiring consent. But given the established relationship and context around this evening, Yunior is in no position to provide that consent. He is in a purely vulnerable position 
before Beto, who follows up "Let's go" with "Unless of course you're not feeling good" (Díaz, Drown 105). Beto here is not requesting, he is demanding. The only way out for Yunior is to admit that he isn't feeling good, putting him in a position of weakness that his mask can't abide. It's an all-too-common tactic among predatory men who feel entitled to bodies they are attracted to, to put the onus on the person whose body they are seeking. It instills guilt in the unwilling party for saying no, and rarely stops at a single dismissal. If the context weren't enough, Yunior's panicked exit and Beto's laughter at it speak volumes:

I had my eyes closed and the television was on and when the hallway door crashed open, he jumped up and I nearly cut my dick off struggling with my shorts. It's just the neighbor, he said, laughing. He was laughing, but I was saying, Fuck this, and getting my clothes on. (Díaz, Drown 106)

Not only is Yunior terrified to be discovered in this position, but in his panic, he almost removes the primary traditional signifier of his masculinity. Whether or not it was a real risk, it tells you how vulnerable Yunior feels in that moment.

Three weeks later, Beto goes to college, where he presumably moves on scot-free and doesn't think of Yunior again, or at least never makes another effort to see him. Yunior is a notch on the metaphorical bedpost, left to deal with the aftermath alone. Yunior at this point stays at home and takes up selling drugs. He compares himself again to junk trapped in the tides, never considering that his own understanding is the tide itself, holding him suspended in limbo.

This story often gets singularly read, painting Yunior as homophobic and Beto as a sympathetic character attempting to come onto his friend in the way that young men do. As Masiki writes, "Much of the literature on "Drown" discounts the possibility of Beto as someone who 
traumatizes Yunior" (Masiki 201). Instead they tend to "interpret Beto as a benign seducer, and Yunior as a homophobe or closeted homosexual" (Masiki 201). For example, in a chapter deconstructing masculinity in Díaz's works, Jason Cortés references "Drown" as enforcing homosocial relations in Díaz's writing as purely defined by heterosexual conquest, stating that Yunior "feels estranged from his best friend 'Beto' because of his homosexual encounters" (Cortés 113). Readings like this put the emphasis wholly on Yunior's response, neglecting the framework of Beto's aggressive coming onto Yunior. Given Yunior's general self-presentation as the macho tíguero, it is easy to fall prey to the sympathetic Beto and take Yunior's cold narration as disgust at the act itself and not the dubious consent.

It seems to me that this response, at least in recent years, stems from a societal shift to recognize and disparage harmful gay stereotypes, like the over-active, predatory gay man. Paired with Yunior's self-depiction as a womanizer, it becomes all too easy to shift the onus onto his response, an apparent disgust at his friend's behavior, rather than a trauma-induced response linked to childhood abuse. Given the context of his works as a whole, it seems Díaz is using this rare gay character in Beto not to enforce a stereotype, but to showcase that the traits of suciodom, the sexual aggression and victimization, are not limited to the acts of heterosexual men, and that heterosexual men, even as the most common perpetrators, are not immune to becoming victims themselves, a concept that Díaz explores from another often untouched angle with "Miss Lora."

"Miss Lora" poses a similar issue of male sexual vulnerability and trauma. Taking place in the same time frame of Yunior's life that he is reminiscing on in "Drown," this story sees a Yunior who hasn't yet grown into his sucio lifestyle begrudging his girlfriend who refuses to have sex with him. He ends up cheating on her with a much older woman, Miss Lora, supposedly 
kickstarting his "suciogenesis," a term coined by Masiki to represent Yunior's development into the rampant cheater we see through much of the rest of Díaz's stories.

Notably, "Miss Lora" is written in second person, looking back on the events from an external or reflective stance, rather than direct memory, as "Drown" was. This could be interpreted as an older Yunior, who we see in much of that collection, recounting events directly to his past self, or as Díaz speaking directly to Yunior. Given the similarities of their circumstances, it could possibly be interpreted as both. In this odd overlap of fictional narrator and fictional listener, the reader is dragged along as both a voyeur observing Yunior's life without the consent of his usual first-person narration, and as a victim as the story and judgment are imprinted on them with every "You" declaration the narrator makes. We begin with the ominous "Years later you would wonder if it hadn't been for your brother would you have done it?" (Díaz, Lose Her 153) Rafa is the eternal metric by which Yunior measures his life. Rafa, who claims he would have sex with any woman, who brags about it to his own mother, who embodies tíguerismo, and who fights against the image of himself as a cancer patient until the very end, seemingly more concerned with looking weak than actually being weak. Even in death, Rafa's masculine dominance lingers over Yunior.

At this point, Yunior has not had sex. His girlfriend, Paloma, patently refuses him, more focused on her studies, concerned that any mistake will trap her in their neighborhood forever. "Why is sex with me a mistake, you demanded, but she just shook her head, pulled your hand out of her pants" (Díaz, Lose Her 155). Paloma here is exercising every aspect of freedom that Yunior does not get in "Drown." She directly removes his unwanted hand from her pants and declares that she won't be prey to sex she doesn't want and will move forward to college on the path she sees as making something of herself. In doing this, Paloma becomes the embodiment of what Yunior could not be in "Drown." She defends herself, she owns her future, and she gets out. Paloma never 
has to consider herself as debris caught in the tide. And along the way, she tries to convince Yunior to focus on his studies, to elevate him alongside her.

Meanwhile, Yunior is having terrible nightmares about the end of the world, in which his body is decimated in any number of horrific ways. And each time, he wakes up "biting [his] own tongue in terror, the blood dribbling down [his] chin" (Díaz, Lose Her 155). He is obsessed with apocalyptic fiction, with the world ending, and with his own horrible death alongside it. But that isn't the reason for the nightmares. Yunior, like Díaz, is haunted by his molestation, and his selfdestructive nightmares have taken on the flavor of the books he adores so much. And rather than look for a way to lift himself out of this pit, Yunior flails. He meets Miss Lora and he falls even deeper.

Miss Lora is a friend of his mother. One day, when she is visiting, she begins a conversation with Yunior, and she listens when Yunior talks about his apocalyptic fiction. The two begin speaking and he learns that she also enjoys the self-destructive fantasy stories. They talk for a while, and then Miss Lora puts a hand on Yunior's shoulder, and he falls hard. Yunior is not seeking romantic attention at first, but he is "at the age when [he] could fall in love with a girl over an expression, over a gesture" (Díaz, "Lose Her" 154). When Miss Lora puts her hand on his shoulder, he notices her eyes, and in that moment, he's hooked. "People always touched you. You were used to it. You were an amateur weightlifter, something else you did to keep your mind off the shit of your life. [...] Most of the time it didn't bother you, the way girls and sometimes guys felt you up. But with Miss Lora you could tell something was different” (Díaz, "Lose Her” 156). At first, this seems to be implying that Miss Lora is different in a good way, preferred over the crowd, but there is an underlying shadow to that thought. Most of the time it didn't bother him, but with Miss Lora, it was different, perhaps implying that it did bother him. Yunior's body 
building seems to develop as an attempt to run from his past as a victim of sexual assault. He doubles down on non-sexual masculinity, lifting weights, which backfires in that it draws people to want to touch him, often without consent as we've seen at least twice between these two stories. What's more, in this moment, "and sometimes guys" seems to invoke Beto, or perhaps more men we will never know the names of.

Regardless of how Yunior feels in that moment, he finds himself head over heels for Miss Lora: nervous, a little frightened, but eager. The two agree that they should get together to watch a particular apocalypse movie together, and to Yunior's surprise, she enforces the idea, drawing him in.

It bears mentioning that Miss Lora has an atypical body type, at least relative to established traditional gender performance present in Díaz's stories:

Miss Lora was too skinny. Had no hips whatsoever. No breasts, either, no ass, even her hair failed to make the grade. She had her eyes, sure, but what she was most famous for in the neighborhood were her muscles. Not that she had huge ones like [Yunior] - chick was just wiry like a motherfucker, every single fiber standing out in outlandish definition. (Díaz, Lose Her 157-158)

Miss Lora is extremely muscular, and not at all traditionally feminine. We've established working out, and becoming more masculine, is often a sign of attempting to overcome sexual trauma in these stories. Miss Lora here embodies performative masculinity. Her body is described as masculine, and her behavior as she increasingly draws Yunior in is more in line with the mold Rafa sets than any other female character we come across. Though Yunior presents as more willing to engage with Miss Lora throughout this story, she is enacting her power upon him the same way 
Beto did, and his struggle and the clear presence of his trauma throughout indicate his struggle, despite his attempted rally to action.

After their first meeting, Miss Lora runs into Yunior again and reiterates that he should come over to watch that film with her. His response, while agreeable, is troubling. "Maybe if you were someone else you would have the discipline to duck the whole thing but you are your father's son and your brother's brother" (Díaz, Lose Her 162). Before anything has actually occurred, Yunior is not only taking the blame for what happens next, he is acting as if the result is preordained due to his lineage. This is the chronological beginning of the character's understanding of fukú, but it is also placing guilt on himself for the situation he is about to dive into while he is still a victim. His father and brother are "sucios of the worst kind and now it's official: you are one, too. You had hoped the gene missed you, skipped a generation, but clearly you were kidding yourself" (Díaz, Lose Her 165). It isn’t even positioned as a poor choice. Yunior sees his transformation into a sucio as set out for him in his genes. Masiki notes that the word "genes" appears three times in This is How You Lose Her, twice in "Miss Lora." He takes this concept in stride in his analysis, examining Rafa, as well as Yunior's father, and grandfather, all of whom are explicitly defined as sucios, and pondering a genetic component, the second half of his aforementioned "suciogenesis," in which Yunior through combination of environment and genetics physically becomes a sucio. These gene references, Masiki notes, "reflect the late twentieth- and early twenty-first-century popular science books, articles, and lectures on the putative relationship between hypermasculinity, promiscuity, romantic infidelity, and genetics" (Masiki).

While I think it is an interesting interpretation to take a "timely" concept like this in stride, I wish to approach from a more contemporary stance. It is not a gene that Yunior and his family 
have inherited, it is a meme. Yunior did not inherit an unavoidable, genetic predilection toward cheating from his family, he learned it from every individual he came in contact with who ever believed, bought into, or made reference to tíguerismo, to suciodom, to hypermasculinity of any sort. In this case, that meme is fukú. A culturally inherited understanding that the only way to claim ownership of his gender, sexuality, and heritage, is through this particular, heavily sexual performance.

Yunior is not a genetic predator incapable of stopping himself, he is a deeply traumatized teenager, falling into a self-destructive pattern that he's been taught is the only means to cope, and Miss Lora is an adult, taking advantage of that, but at no point is Yunior capable of stepping back and realizing that. Despite his sexual awareness, he is still a child, and this affair is only another version of his experience with Beto, albeit with someone who doesn't immediately instill fear and sickness in him. They get together to watch the movie, but:

...you two only last an hour before she reaches over and takes off your glasses and kisses you. This time your wits are back so you try to find the strength to fight her off.

I can't, you say.

And just before she pops your rabo in her mouth she says: Really? (Díaz, Lose Her 164)

The events of this scene echo the nights with Beto, swapping porn for a traditional movie, and in this environment, with a removed narrator, we get some insight into Yunior's thoughts. He thinks of Paloma, or at least he's “trying to think of her but what [he's] doing is holding Miss Lora's tresses like reins and urging her head to keep its wonderful rhythm." (Díaz, Lose Her 164) Yunior 
succumbs to Miss Lora, and unlike his escape from Beto, he continues coming back for more. Initially, he tries to make it a one-off, but he finds that impossible:

You try to be reasonable. You try to control yourself, to be smooth. But you're at her apartment every fucking day. The one time you try to skip, you recant and end up slipping out of your apartment at three in the morning and knocking furtively on her door until she lets you in. (Díaz, Lose Her 166-167)

This relationship, the seeming route to sexual freedom, becomes another source of selfcreated guilt for Yunior. He can't go a day without returning to her feeling like he has done something to harm her in his absence. Pleasant as his time with her is, the experience is doing him more harm than good. "It should be the greatest thing, so why are your dreams worse? Why is there more blood in the sink in the morning?" (Díaz, Lose Her 167) This relationship is destroying Yunior, but he isn't the only one acting to avoid a troubled past. "She sleeps with a mouth guard. And she covers her eyes with a mask" (Díaz, Lose Her 168). This line almost slips into the background as a detail of his familiarity with Miss Lora, but it tells so much. Miss Lora sleeps with a mouth guard because she also bites her tongue at night. We never get details on what happened to Miss Lora when she was younger, apart from that her growing up was unpleasant, but it seems a safe bet that there is trauma in her past. Between the musculature, the apocalyptic movies, the affair and the mouthguard. it seems clear Miss Lora was a victim herself, and in her attempts to regain control, she is victimizing Yunior. The cycle of fukú.

As he starts his senior year, Miss Lora starts teaching at his high school, and the connection between the two starts to deteriorate. She enters into a relationship with his science teacher, Mr. Everson. Miss Lora starts to move on, but her presence haunts Yunior. He realizes he was just a 
temporary fling for her, and yet she lingers in his life, a constant reminder. She shows up to his graduation with his mother, "wearing a red dress because you once told her it was your favorite color and underneath matching underwear" (Díaz, Lose Her 172). But she pushes him away, gently if possible, in favor of her newfound adult relationship. At the same time, Paloma heads off to college and leaves Yunior, who stays and drifts through life at home, caught in the aftermath of his time with Miss Lora. He tries to stay, to make her keep him, but she tries to push him onward, to college. She offers to pay his admission fees, but he is too caught up in everything else, in her. Even after he manages to let her go, the hole where the secret that was their relationship once was remains.

Time passes. Yunior eventually moves on, at least enough to go to college. But as he graduates, there she is again, "standing alone in a red dress. She is finally starting to put on weight; it looks good on her." (Díaz, Lose Her 175) Perhaps this means Miss Lora has found closure, and has managed to move on from her past. But this clue is all we get. They don't speak, and instead we get the briefest run down. Miss Lora moves away. Yunior eventually tries to track her down, but turns up nothing, left with only a picture of the two of them and the memories.

The ending is not as abrupt and traumatic as his experience with Beto, but it seems to have hurt Yunior just as deeply, perhaps even more so because of the length and his attempt at willingness, repeatedly harming himself to try to act "normal." If nothing else, it teaches him the fleeting happiness that can come with a sexual relationship, a lesson which sticks with him through much of the rest of his life and which will be reflected in his closing thoughts in the titular last story in This is How You Lose Her. 
At this point, Yunior is set on the path that he will continue on for years. Stories like "How to Date a Browngirl, Blackgirl, Whitegirl, or Halfie," in Drown, and "This is How You Lose Her" depict the soon-to-be rampant womanizing which will carry him through much of the stories we see. Through these stories, we see less of Yunior's past, less of himself, and far more of his mask. Even when he laments the breakups that his behavior directly leads to, it's filtered through his supposed inability to stop, rather than regret over continuing the tíguero act itself, not even during the events of Oscar Wao, where we see Yunior meet, date, and break the heart of his supposed one true love, Oscar's sister, Lola de Leon.

Oscar and Lola at this point need to be explained. In The Brief and Wondrous Life of Oscar Wao, Yunior serves as a narrator who himself also appears as a character encountered by the novel's protagonist, Oscar, in his college years at Rutgers. Oscar, whose "brief wondrous life" we are primarily following through the novel, is a "ghettonerd." Overweight, covered in acne, and primarily interested in genres (Sci-fi, fantasy, comic books), Oscar's last luck with the ladies was an ill-fated attempt to court two girls at seven years old, and from that point it is all downhill. Oscar is the polar opposite of Yunior, who by the time of the novel has perfected his mask and, with the focus on Oscar, paints himself as the pinnacle of machismo, casually ignoring the fact that all the sci-fi and fantasy references (from Akira to Watchmen and far beyond the Outer Rim of now-mainstream nerddom) are his own inclusion.

Yunior and Oscar are lined up in the narrative as two sides of a coin. Oscar the overweight nerd who can't draw a girl's eye to save his life, and Yunior the muscular tíguero who can’t keep his eyes (or anything else) off a girl to save his. Yunior blames fukú for Oscar's state of affairs throughout the novel: a string of catastrophic almost-relationships, depression, attempted suicide, and near the end, when he finally meets a woman who gives him the time of day (Ybón Pimentel, 
the aforementioned capitán's girlfriend), he gets beaten nearly to death, is miraculously rescued, then persists in pursuing her and when he is found out, gets beaten the rest of the way. This sequence is painted as a victory in Yunior's terms. Oscar finally kisses a woman, proving he has some semblance of Dominican masculinity after all, and even though he dies, he does so as a man. Never mind the fact that Ybón was terrified for the weeks he was doing this, fearful for retaliation toward Oscar, for herself. "She was miserable when she saw him, and miserable, she would tell him later, when she didn't, convinced that he'd gotten killed" (Oscar Wao 317-318). Oscar seems to be inflicting on Ybón the same feeling that Yunior received from Miss Lora, and in the end, her fears are justified, but Yunior celebrates it all the same. This, the apparently wondrous bit of Oscar's brief, wondrous life. Maybe it's just a friend finding something to highlight in his dead friend's mostly miserable story, circling back and saving him from emasculation. Despite this depressing kneeling to the power of fukú, there is an undercurrent that dates back to his conversation with Rafa in "Ysrael," when he declares that Ysrael will get better and Rafa firmly denies it. Through it all, there's a shred of hope in Yunior that lasts. If even Oscar, who embodies the complete loss of Dominican masculinity, can come back around in the end, can't there also be hope for him? He almost directly addresses this when he begins telling the story of Oscar and Ybón: "I know I've thrown a lot of sci-fi and fantasy in the mix but this is supposed to be a true account of the Brief Wondrous Life of Oscar Wao. Can't we believe that an Ybón can exist and that a brother like Oscar might be due a little luck after twenty-three years?" (Oscar Wao 285) As with Ysrael, Yunior is seeking hope in Oscar's life, but he's asking just as much for himself, and it is bearing that in mind that we must discuss the ending of Oscar Wao and the final story in This is How You Lose Her, "The Cheater's Guide to Love." 
After the events of "Miss Lora," and throughout Oscar Wao, Yunior's mask is at its peak stability. He is cheating even when he has a relationship he cares about. He is seemingly unable to stop himself, spiraling deeper and deeper into suciodom, and into the pit of fukú. Even when he has a chance with Lola, Oscar's sister. Lola, who herself was a victim of sexual assault at a young age, who undergoes her own struggle on the other side of the binary created by Dominican masculinity, who shaves her head, acts aggressively in the face of boys like Yunior, and takes the reins of her own life as much as she can. When he has a chance with this strong woman he is very deeply in love with, he cheats again, and blows his shot. It isn't until "The Cheater's Guide to Love," the final story in This is How You Lose Her, and the closing section of Oscar Wao that we see a Yunior forced to confront his mask.

"The Cheater's Guide to Love," begins "Your girl catches you cheating. (Well, actually she's your fiancée, but hey, in a bit it so won't matter.)" (Lose Her 179). It's nothing new for Yunior. It's not even the first time in this collection. Over a six-year period, he cheated with fifty different women, and because he never clears his emails, she finds out about all of them at once. He tries to salvage the relationship, but it's impossible, and through the rest of the story, we watch his five-year collapse. He tries to date, he fails; he dreams about his ex, always bad. Toward the end, he is attempting, and managing, slowly, to get things together. He is taking it slowly with a woman, and he is keeping it together. One night, he pulls out the Doomsday book, "copies of all the emails and fotos from the cheating days, the ones the ex found and compiled and mailed to you a month after she ended it" (Lose Her 216). He reads through it twice, and admits that she was right to dump him, shedding a small layer of the act he's kept up so long it no longer feels like one. His friend comments that he should write "The Cheater's Guide to Love," and he starts. He writes a few pages, which he doesn't immediately want to destroy, for the first time in a long time: 
It's a start, you say to the room.

That's about it. In the months that follow you bend to the work, because it feels like hope, like grace-and because you know in your lying cheater's heart that sometimes a start is all we ever get. (Lose Her 217)

Sometimes a start is all we ever get. Certainly, this is true of Yunior's relationships, but it could equally be true of his life. The bus ride in "Ysrael," was the end of the start for the Yunior that might have been, and the start of the Yunior that we see through the rest of Díaz's work. Obviously, this focus discounts all the bad ends implicit in so many starts, but perhaps after so long, that's the point. Yunior is starting to dwell not on the ends, but the chance at new starts, however fleeting they may be. And it seems to work.

At the end of Oscar Wao, years after Oscar's death, Yunior is married. He makes no reference to cheating, which he's never been shy about acknowledging to that point. At most, we get a denoted low point:

Took ten years to the day, went through more lousy shit than you could imagine, was lost for a good long while — no Lola, no me, no nothing — until finally I woke up next to somebody I didn't give two shits about, my upper lip covered in coke-snot and coke-blood and I said, OK, Wao, OK. You win. (Oscar Wao 325)

Where this all fits as a timeline is murky, but what we learn is that Yunior is a composition and creative writing teacher at Middlesex Community College. He has "a wife I adore and who adores me $[\ldots]$ whom I do not deserve, and sometimes we even make vague noises about having children" (Oscar Wao 326). He keeps in touch with Lola, who, despite his cheating, lets him 
around, though they only ever discuss Oscar. He ends the novel waxing poetically about Lola's daughter, a happy child, who wears three azabaches, charms against the fukú. He dreams of her one day coming to visit when she is grown, going through the refrigerators he keeps Oscar's writings and comic collection in and piecing it all together in a way he seems to think he's unable to. "This is what, on my best days, I hope. I dream" (Oscar Wao 331). He then ends on a quote from Watchmen, Alan Moore and Dave Gibbons' classic comic book, in which Adrian Veidt, a man who murdered millions in an attempt to stop the escalation of the Cold War from ending humanity as a whole.

The panel where Adrian Veidt and Dr. Manhattan are having their last convo. After the mutant brain has destroyed New York City; after Dr. Manhattan has murdered Rorschach; after Veidt's plan has succeeded in "saving the world."

Veidt says: "I did the right thing, didn't I? It all worked out in the end."

And Manhattan, before fading from our Universe, replies: "In the end? Nothing ends, Adrian. Nothing ever ends. (Oscar Wao 331)

Dr. Manhattan is nigh-omniscient, once a man, now a demi-god, who experiences the entire span of his existence at once and has become slowly detached from his humanity. When he, able to see functionally infinitely into the future, says "Nothing ever ends," Adrian is left to ponder what he has done, and what "in the end" truly means, and the reader is left to consider if the morally grey antagonist's actions were truly worth it, with no single conclusion.

Sometimes a start is all we ever get.

Nothing ever ends. 
Yunior, and Díaz, choose these notes to end on for a reason. The latter was written first, even if it came chronologically later in Yunior's story, and on its own presents a somber ending. If nothing ever ends, why bother fighting at all? Why not succumb to fukú? To your fate? But on the other hand, perhaps Fukú is as questionably permanent as the peace in the wake of Veidt's "solution." I think it comes down to a simpler take than these big picture questions.

Nothing ever ends, and sometimes a start is all we ever get. Yunior when he writes the latter seems to be choosing to focus on the possibly temporary, rather than dwelling on the end, a stark contrast to his earlier obsession with apocalyptic fiction. The end will come, some way or another, but dwelling on it only serves to ruin the time you have. The start.

And in that moment, it's easy to bask in Yunior's reflection. It's easy to forget that the origin of Yunior's "Cheater's Guide to Love" is a stack of printed emails recording his cheating with fifty other women, during the course of one relationship, a situation that Junot Díaz very much lived.

Y- simply printed out all the e-mails between me and all my other girls, all my bullshit seduction attempts, all the photos, had the evidence of my betrayals bound, and when I came home from one of my trip handed them to me.

When I realized what she'd given me I blacked out.

Which is what tends to happen when the world ends. (Díaz, "The Silence")

Like Yunior, Díaz says he lost years (two, not five) after being dumped, and like Yunior, Díaz "hit rock bottom" before he was able to drag himself back up and find some semblance of stability. But Yunior acknowledges that she "did the right thing" in dumping him. Díaz explains 
that "She kept the apartment, the ring, her family, our friends. I got Boston. We never saw each other again" (Díaz, "The Silence"), then details his collapse and recovery without mentioning her again. The story becomes his recovery from the depression their break-up caused, with no acknowledgment of the circumstances he created to lead to that break-up. Díaz becomes the victim. He writes about how he bared it all for his current partner, and explains that he has grown and changed, how he regularly attends therapy, and how he is in a relationship with a woman who "knows everything about my past." But in this instance, the crux of that everything is the abuse he suffered and kept a secret for so many years, not on his own actions.

Yunior has no such story to tell. Though his story is incredibly similar to Díaz's, he was written at a time when Díaz's own history was a secret, and his past abuse is shrouded in subtext or actively shrugged off by Yunior's narration. If he came to terms with what happened when he was a child, or with Beto or Miss Lora, or the aunt who used to "pinch his pinga," if he shared these stories with his wife, is left for the reader to wonder at, along with much of Yunior's life. We know about the abuse he suffered (at least some of it), and we know he cheated relentlessly for as long as it was sustainable. We can't know how many women got hurt, though we know there are many. Three books can only show so much of a life, and every moment by virtue of existing in the page becomes relevant to the total narrative. What we see is a deeply hurt man, who reaches out to others without fear of the hurt he might spread, and who only seems to show remorse when that behavior inevitably catches up to him and hurts him again. We cannot know how many women Yunior treated exactly like Beto treated him. There are so many that they become a statistic, a prop to illustrate a character flaw. They are so ubiquitous by the end that they are easily dismissed by an acknowledgment to an empty room that his ex was correct to dump him. 
Yunior is not asking for forgiveness, but he ends "Cheater's Guide" writing a book about his ex, and presumably about the cheating that led to them parting. We can't know what the content of that book will be, or if it ever sees publication. Maybe it frames what he did as reprehensible, maybe it explores why he did it, or maybe it excuses what he did in as many words while telling the world about his own trauma.

Given that Yunior, at the end of Oscar Wao, is married happily, waxing poetic on the idea that "Nothing ever ends," and that fukú will undoubtedly someday come for Lola's daughter, the beacon of hope for the future, Yunior may have overcome his own need to overcompensate to hide his past, but he is still firmly entrenched in a worldview that the cycle of abuse is inevitable. And given the saturation of it in the world he lives in, that is reasonable, but his acceptance of it makes him complicit in its perpetuity. Beyond direct victims and perpetrators, there are those so rooted in established hierarchies, in perceived "hard truths," that they see the world as unchangeable, that all they can do is take joy in the starts they have, hide away the troubles of the past, find their own peace and hold onto it, damn all others.

Yunior may not be forgivable, but forgiveness is the wrong question. He is a byproduct of a complicated web of influences that pushed him to become the man he did. He is also an individual with his own agency who hurt innumerable people, and he is seemingly able to learn from and overcome his past behavior, whether or not he chooses to act on the system the guided him to do so in the first place.

The point at which Yunior and Díaz diverge cannot be ignored. Where Yunior becomes a teacher at a community college and quietly acknowledges the harm he caused, Díaz wins the Pulitzer Prize writing about a man deeply entrenched in that harm. He teaches at the prestigious 
Massachusetts Institute of Technology, he is fiction editor for The Boston Review, he is a chair on the Pulitzer Prize board, for a time. Yunior somberly reflects on the inevitability of crushing toxic masculinity and the victims it creates, while Díaz calls listening to women speaking out about abuse one of the worst things he's ever written and actively contributes to the culture that allows such victimization to persist.

Masiki writes in closing that "Díaz's disclosure about Yunior's rape asks readers to reassess any impulse to categorically condemn Yunior for his chronic infidelity. Díaz invites careful readers to find traces of humanity and suffering behind Yunior's mask of tíguerismo."

I'm inclined to agree, but I worry that in showcasing the humanity and suffering underneath the mask, too much of the humanity and suffering caused by it falls by the wayside, and the wider tragedy becomes set dressing while the narrative applauds a man whose major accomplishment is to shift from active to passive participation.

Maybe someday, Díaz will write another book for Yunior, and in that one, we'll see a Yunior who combats the systems he has spent so much of his life riddled in and makes an effort to make a change. Or maybe we'll find that his "Cheater's Guide" spent a little too much time glamourizing the man and his personal suffering, and too little on all those he hurt. After all, nothing ever ends. 


\section{References}

Alter, A., Bromwich, J., \& Cave, D. (2018, May 04). The Writer Zinzi Clemmons Accuses Junot Díaz of Forcibly Kissing Her. Retrieved from https://www.nytimes.com/2018/05/04/books/junot-Díaz-accusations.html. Accessed 12 June 2020.

Butler, Judith. "Melancholy Gender-Refused Identification.” Psychoanalytic Dialogues, vol. 5, no. 2, 1995, pp. 165-180.

Byrne, M. (2018, May 4). Monica Byrne - I've been waiting for this one to come out for a... Retrieved from https://www.facebook.com/monicabyrne13/posts/10105748635455288. Accessed 12 June 2020.

Cortes, Jason. MACHO ETHICS: Masculinity and Self-Representation in Latino-Caribbean Narrative. Bucknell Univ Press, 2016.

Díaz, Junot. Drown. Riverhead Books, 1996.

---. The Brief Wondrous Life of Oscar Wao. Riverhead Books, 2008.

---. This Is How You Lose Her. Riverhead Books, 2013.

---. "Junot Díaz: The Legacy of Childhood Trauma." The New Yorker, The New Yorker, 9 Apr. 2018, www.newyorker.com/magazine/2018/04/16/the-silence-the-legacy-of-childhoodtrauma. Accessed 5 May 2018. 
Maria Machado, C. (2018, May 4). Carmen Maria Machado on Twitter. Retrieved from https://twitter.com/carmenmmachado/status/992318598398992384. Accessed 12 June 2020.

Masiki, Trent. "Ambiguous Seductions: Doppelgängers, Suciogenesis, and the Mask of Tíguerismo in Junot Díaz’s "Drown” and "Miss Lora"." MELUS: Multi-Ethnic Literature of the United States 43.4 (2018).

Sáez, Elena Machado. “Dictating Desire, Dictating Diaspora: Junot Díaz’s The Brief Wondrous Life of Oscar Wao as Foundational Romance.” Contemporary Literature, vol. 52, no. 3, 2011, pp. 522-555.

Saldívar, José David. “Conjectures on 'Americanity’ and Junot Díaz’s 'Fukú Americanus' in The Brief Wondrous Life of Oscar Wao.” The Global South, vol. 5, no. 1, 2011, p. 120.

Schaub, Michael. Junot Díaz Denies Misconduct Allegations; His Accusers Respond. 2 July 2018, www.latimes.com/books/la-et-jc-junot-Díaz-20180702-story.html. Accessed 9 July 2020. 